\title{
Heterogeneity of government social spending in European Union countries
}

\author{
Anna Magdalena Korzeniowska* (1)
}

\begin{abstract}
Social expenditure plays an important role in European Union (EU) countries. It improves the lives of citizens whose welfare is endangered due to poverty or illness. However, social expenditure represents a considerable share of the budgets of EU member states. Despite evident similarities in their levels of development, EU countries show apparent differences in social expenditure levels. Therefore, this work aims to determine the similarities and differences between EU countries in this regard. The analysis uses clustering methods, such as hierarchical cluster analysis and the k-means, to divide countries into homogeneous groups. The research demonstrates significant differences between EU countries in the years 2008-2018, which resulted in a low number of objects (countries) in the identified groups. In the case of 6 out of 28 countries, it was not possible to assign them to any group. The research proves that EU countries should take more care when organising their social policy, taking into consideration cultural and social factors.
\end{abstract}

Keywords: Government social spending, Household finance, Heterogeneity of EU countries

\section{Introduction}

The government social expenditure is part of social policy and comprises a considerable share of the EU member states' budgets. These funds are dedicated to diverse social security programmes. The main priorities of government social expenditure focus on combating social exclusion and reducing income inequality [7, p. 18]. However, it has been pointed out that the amount of government expenditure does not achieve the expected results in reducing the inequality gap. Findings from these studies prove that the same improvements in the social situation could be achieved using better policy rather than higher volumes of spendings $[2,3,29,48]$.

Many researchers have pointed out that the social policy in the EU is uncoordinated and difficult to understand [11, p. 23], even though social policy was included in the Lisbon's Strategy launched in 2000, and its descendant, the Europe 2020 strategy, launched in 2010. The goal set in the Europe 2020 strategy for smart, sustainable and

*Correspondence: anna.korzeniowska@umcs.lublin.pl

Faculty of Economics, Maria Curie-Skłodowska University in Lublin, Maria Curie-Skłodowska Sq. 5, 20-031 Lublin, Poland inclusive growth was to ensure an innovative, sustainable and inclusive economy in the EU. The strategy presented a set of indicators to evaluate the progress of development. All countries were obliged to attain their particular targets, which was intended to boost the economy and society of the whole EU. One of the three priorities was 'Inclusive growth: fostering a high-employment economy delivering social and territorial cohesion' $[18$, p. 3]. The aim was to reduce the number of people at risk of poverty or social exclusion by over 20 million. Other targets related to the remaining two priorities included: increasing the employment rate of the population aged 20-64, reducing the dropout rate in early education and increasing the share of the population aged 30-34 having completed tertiary education. Unfortunately, these indicators still have not reached their targets, with the indicator of poverty in the EU staying above the mark [17]. One reason for this situation is the heterogeneity of EU societies $[10,36]$ and the differences in social policy across EU countries. The diversity of EU economies and their social politics limits the development of EU countries [33]. Yet, the full integration of social politics is not the proper solution, as the heterogeneity of countries must also be 
taken into consideration [26]. That is why there is a need to recognise these differences.

EU countries are highly developed, and they have complex public schemes of social securities, often supported by private programmes. However, there are certain differences in social policies that negatively influence social cohesion [16]. Some of these differences are observed in the governments' social expenditure, in the structure of this expenditure and in social policies' effectiveness [8, 15]. The reasons for the diversity in the EU countries' economies are attributed to cultural and language factors [27, 30]. Chen [14] also adds that cultural factors are subject to change due to globalisation. He argues that the development of tourism and migration for jobs brings about changes in the values and principles that consumers follow.

Institutional factors are another aspect influencing the differentiation of countries. These factors include the level of development of financial markets, the accessibility of specific financial instruments $[8,9,40]$ and such variables as the functioning of tax and pension schemes. The historical background discussed by Fessler and Schürz [23] is of no less importance. The more developed domestic financial markets are in the degree to which they allow households access to diverse financial instruments, the greater the knowledge of these instruments is in society and the higher preference to use them. The development of financial markets and historical circumstances are believed to be the main reasons for differences between Western European and Central and Eastern European (CEE) countries [47]. The same historical circumstances influence the lower propensity to save but, at the same time, a higher tendency to demand social aid among the CEE countries' citizens. Social policy is also connected with the countries' welfare model. Antonelli and De Bonis [6] identify four such models among the original EU countries: the Scandinavian model (Denmark, Finland and Sweden), the continental model (Austria, Belgium, France, Germany and Luxembourg), the Anglo-Saxon model (Ireland and the United Kingdom) and the Mediterranean model (Italy, Spain, Greece and Portugal). Multiple studies focus on a synthetic measure of the efficiency of social expenditure $[15,34,44,50]$. However, studies focussed exclusively on the structure of the government social expenditure are lacking.

It is assumed that social security contributions paid by persons receiving income are the primary source of financing this expenditure. In practice, the budgets of social security schemes are often not balanced, and they have to be funded from other sources of budget revenues. Additionally, it was proven that there is some negative impact of social expenditure within social security schemes on private saving and employment of women [38].

In the hypothesis of the life cycle [4], social security contributions, mainly retirement pensions, are viewed as pseudo-tax-reducing current revenues, which negatively affect private finances. Across the whole economy, their impact depends on the population's age structure, and hence, on the relation between the amount of the contributions paid and the amount of securities paid out [20, p. 5].

Empirical analyses carried out in the United States pointed out that the emergence of social securities schemes played a significant role in reducing aggregated savings and capital resources in the US economy. Experts explained this phenomenon in two ways: from the perspective of the elderly and the youth [38, p. 316]. Among older people, access to pension schemes, which give entitlement to some income, considerably increased early [12, p. 372]. Regarding younger persons, access to social security funds within social security schemes makes them less willing to accumulate financial resources towards future pensions, which has an adverse effect on private savings. The final conclusion drawn from the long-term analyses indicates the benefits guaranteed by social security systems have a negative impact on household savings [21].

The introduction of family and child benefits was supposed to lessen the work-family conflict [22] and improve women's economic activity. Its aims were twofold: financial support for poor children to enhance their economic situation and financial support to young families to raise fertility rates in countries with a high demographic dependency ratio. These aims are crucial given ageing societies in EU countries. Most EU countries have implemented some form of child benefits [13]. However, it is observed that after such implementation, the employment rate of women with children often decreases [42].

At the onset, social securities schemes were subsidised by employers or state budgets. At present, a number of countries seek solutions that would support non-profitable social securities schemes. Especially given ageing societies and longer life expectancy, the relation of revenues from contributions to social expenditure continues to deteriorate. Additionally, private persons covered by social securities schemes do not take actions towards accumulating savings they could benefit from during their retirement. This issue refers, in particular, to persons with high earnings [28]. Thus, the problem is how to respond to the needs of society demanding social support and at the same time keep national public spending under control and, most often, reduce it [5]. 
Therefore, this work aims to determine the similarities and differences between EU countries in the structure of their social expenditure. Understanding these similarities and differences may help better accommodate various social policies to fight inequality and poverty among EU citizens.

The paper is structured as follows. "Methods" section presents the data and methodology used. "Results and discussion" section gives the results and the discussion, and "Conclusions" section presents the conclusions.

\section{Methods}

The data analysed in this study came from the Eurostat database, General government expenditure by function (COFOG [gov_10a_exp]), and cover the years 20082018. For the purpose of international comparison, the data used are presented as a percentage of the gross domestic product (GDP). The EU statistics divide social spending into nine groups: "Sickness and disability", "Old age", "Survivors", "Family and children", "Unemployment", "Housing" and three others hereafter summed up: "R\&D"; "social protection" and "social exclusion Spending on "Sickness and disability" is the healthcare system's expenditure on support for the disabled and their caretakers. The "Old age" group represents spending on pension and retirements schemes. The spendings on "Survivors" are pensions paid by the government to widows, widowers and orphans of persons entitled to social support who have not acquired these rights themselves. "Family and children" is a group of expenditures consisting of childbirth benefits, statutory maternity pay, supplementary feeding of children and other family members and family allowance, among others. "Unemployment" refers to expenditures on unemployment benefits and programmes such as vocational training and retraining, while "Housing" refers to expenditures on housing benefits and building and maintaining public apartments.

The following indicators of distribution were calculated to analyse differences in government social spending between EU countries: coefficient of variation $(V)$, skewness $\left(A_{s}\right)$ and excess kurtosis. The coefficient of skewness, $A_{s}$, measures the skewness of the distribution of a variable in relation to its average. A positive value of this coefficient, so-called right-skewness, indicates that more than $50 \%$ of observed objects have a lower value than the variable's average [45, p. 26].

The analysis of the similarities and dissimilarities of objects (countries) was completed using clustering methods. Grouping, also referred to as clustering or cluster analysis, is a technique of data mining. Similar data are combined into homogeneous groups (clusters) without prior definition or knowledge of these groups' characteristics [1, p. 16]. The main aim of clustering is to identify a structure of unmarked sets of data by objectively grouping them into homogeneous groups while seeking maximum similarity of internal objects within groups and the highest external diversity between groups [51, p. 1857]. The classification methods are not connected with the determination of reasons for similarities and differences identified by using these same methods [31, p. 64].

When analysing clusters, researchers most often apply at least two methods to assign objects to groups. This study used methods based on partitions, including k-means clustering and hierarchical clustering [51, p. 1857]. When the taxonomy of data is in the form of time series, additional solutions may be utilised. Of these, the simplest one used in this study was the analysis of each examined period separately in order to then make the definitive determination of the number of groups and assignment of the objects by comparing the results [37, p. 100].

The hierarchical cluster analysis belongs to the category of agglomerative methods. However, a target number of groups is not assumed a priori [24, p. 579]. Instead, the focus is on the distances between objects and groups that can be measured with different methods [39, p. 373]. In particular, Ward's minimum variance criterion is a recommended method [43, p. 277]. In the k-means clustering method, a certain number of subgroups into which analysed objects are to be divided is determined in advance $[41,46$, p. 95$]$.

One of the tests assessing the correctness of a certain selected number of groups or clusters is based on the pseudo-F statistic $[19,25]$. In this test, the statistic F's value from the variance analysis for a given number of clusters is compared with the statistic F computed for a smaller or bigger number of clusters. Linked with the increase in the number of clusters, a noticeable increase in the value of the statistic F suggests that a higher number of them should be taken. The silhouette index can also be used to assess the selection of a certain number of clusters [35, p. 88]. It allows comparative assessment of the internal content of clusters and their separability [49, p. 420]. This measurement takes values from -1 to 1 , where a value above 0.5 indicates a good structure and above 0.7 , a very good structure of the created groups.

The countries were assigned to clusters using the hierarchical cluster analysis and the results of the Ward method and the k-means clustering, and the findings from particular years were compared. Consequently, it was possible to establish which countries always fell into the same cluster within the whole analysed period. A set of such countries is referred to as a group, and they are marked with the letters A-F.

Finally, the ranking of predictors was completed using the C\&RT model as a measure to calculate the 
importance of predictors. All calculations were run using STATISTICA software.

\section{Results and discussion}

The average value of social expenditure in GDP percentage points ranged from $11.77 \%$ in Malta to $25.35 \%$ in France (Table 1). In nine out of 28 countries, this value exceeded $20 \%$. A minimum value lower than $10 \%$ was observed for Ireland, Lithuania and Malta, while a maximum value higher than $20 \%$ was found in France, Belgium, Germany, Austria, Italy, Greece, Netherlands, Finland, Luxembourg, Slovenia and Portugal.

The highest variability was observed for Ireland $(V=22.97 \%)$ and the second highest in Lithuania $(V=13.34 \%)$. The lowest variability was noted for Austria $(V=2.68 \%)$, closely followed by Germany, Poland and Belgium $(V<3.0 \%)$. The coefficient of variation exceeded $10 \%$ in Hungary, Latvia, and Malta, while its value was below 5\% in the Czech Republic, Denmark, France, Italy, Luxembourg, the Netherlands, Slovakia, Sweden and the UK.

(Piłatowska [45, p. 26]) Right-skewness was calculated for seven countries. In Poland, $A_{s}$ was exceptionally low, indicating that government social spending during the examined period was almost symmetrically distributed around the average. For Luxembourg and Sweden, $A_{s}=0.38$, demonstrating that the distribution of government social spending during this time period was also close to symmetrical. However, in Estonia, Germany, Lithuania and Romania, the dispersion of data was very high, with $A_{s}$ exceeding 1.0, except in Romania where $A_{s}=0.92$. The left side asymmetry of variables was even stronger than on the right side. In Belgium, France and Slovakia, the left-skewness was higher than 2.0, and in nine other countries, it was higher than 1.0. These results indicate that EU countries are a non-homogeneous

Table 1 Social expenditure of the government sector in EU countries in 2008-2018

\begin{tabular}{|c|c|c|c|c|c|c|c|}
\hline \multirow[t]{2}{*}{ Country } & \multicolumn{7}{|c|}{ Social expenditure as \% of GDP } \\
\hline & Average & Min & Max & SD & $A_{s}$ & Excess kurtosis & V \\
\hline Austria & 22.40 & 21.00 & 23.00 & 0.60 & -1.38 & 1.87 & $2.68 \%$ \\
\hline Belgium & 24.44 & 22.50 & 25.20 & 0.72 & -2.18 & 5.84 & $2.94 \%$ \\
\hline Bulgaria & 13.25 & 11.20 & 14.40 & 0.84 & -1.33 & 3.04 & $6.36 \%$ \\
\hline Croatia & 16.01 & 14.00 & 17.00 & 0.82 & -1.41 & 3.24 & $5.11 \%$ \\
\hline Cyprus & 13.06 & 11.00 & 14.20 & 0.90 & -1.23 & 1.85 & $6.87 \%$ \\
\hline Czech Republic & 15.64 & 14.50 & 16.50 & 0.68 & -0.47 & -1.33 & $4.37 \%$ \\
\hline Denmark & 18.21 & 16.20 & 18.90 & 0.86 & -1.45 & 1.91 & $4.70 \%$ \\
\hline Estonia & 13.15 & 11.90 & 15.60 & 1.08 & 1.22 & 1.50 & $8.23 \%$ \\
\hline Finland & 20.73 & 16.90 & 22.40 & 1.62 & -1.32 & 2.05 & $7.83 \%$ \\
\hline France & 25.35 & 23.20 & 26.10 & 0.81 & -2.13 & 5.43 & $3.18 \%$ \\
\hline Germany & 24.02 & 23.30 & 25.60 & 0.67 & 1.47 & 2.15 & $2.80 \%$ \\
\hline Greece & 21.44 & 18.90 & 23.20 & 1.19 & -0.61 & 1.05 & $5.54 \%$ \\
\hline Hungary & 16.25 & 13.10 & 18.80 & 2.00 & -0.34 & -1.49 & $12.28 \%$ \\
\hline Ireland & 13.89 & 9.30 & 17.20 & 3.19 & -0.39 & -1.80 & $22.99 \%$ \\
\hline Italy & 21.89 & 19.60 & 22.80 & 0.95 & -1.49 & 2.50 & $4.34 \%$ \\
\hline Latvia & 11.87 & 8.90 & 14.30 & 1.42 & -0.17 & 1.76 & $11.93 \%$ \\
\hline Lithuania & 13.85 & 12.40 & 18.20 & 1.85 & 1.68 & 2.29 & $13.34 \%$ \\
\hline Luxembourg & 20.15 & 19.00 & 21.70 & 0.83 & 0.38 & -0.52 & $4.14 \%$ \\
\hline Malta & 11.77 & 9.60 & 13.20 & 1.31 & -0.62 & -1.34 & $11.09 \%$ \\
\hline Netherlands & 21.19 & 18.70 & 22.20 & 0.97 & -1.81 & 4.25 & $4.58 \%$ \\
\hline Poland & 16.40 & 15.60 & 17.20 & 0.47 & 0.06 & -0.34 & $2.89 \%$ \\
\hline Portugal & 19.02 & 16.90 & 20.60 & 0.99 & -0.64 & 1.23 & $5.19 \%$ \\
\hline Romania & 12.03 & 10.70 & 13.90 & 0.93 & 0.92 & 0.42 & $7.71 \%$ \\
\hline Slovakia & 18.64 & 16.30 & 19.40 & 0.85 & -2.40 & 6.69 & $4.54 \%$ \\
\hline Slovenia & 19.19 & 17.40 & 20.50 & 1.12 & -0.47 & -1.23 & $5.83 \%$ \\
\hline Spain & 18.07 & 14.90 & 19.50 & 1.23 & -1.77 & 4.60 & $6.79 \%$ \\
\hline Sweden & 16.89 & 16.20 & 17.80 & 0.52 & 0.38 & -0.72 & $3.08 \%$ \\
\hline UK & 15.95 & 14.70 & 16.80 & 0.70 & -0.56 & -1.01 & $4.42 \%$ \\
\hline
\end{tabular}

Source Own calculation based on Eurostat data 
entity; therefore, for further more in-depth analysis, they should be divided into smaller groups.

The excess kurtosis in nine countries was lower than 0 , presenting a platykurtic curve. Thus, the values of government social spending were more dispersed than in normal distribution. The lowest result $(-1.8)$ was in Ireland. The results for the remaining 15 countries again showed very high variability across countries. Leptokurtic kurtosis revealed that the distribution of values around the average was lower than in a normal distribution. In the case of an extreme positive excess kurtosis, the majority of the values are located in the tails of the distribution rather than around the mean. That was the case in many EU countries. The most extreme positive excess kurtosis, with a coefficient higher than 5.0, occurred in the same countries as the highest left-skewness. Overall, these results demonstrate that the government social spending in relation to GDP cannot be analysed with parametric methods.

As mentioned above, government social spending is used to support different needs in society. It may finance pension systems, people suffering from sickness or disability, the unemployed or the homeless. Table 2 presents the division of EU social spending into seven groups referred to as: "Sickness and disability, "Old age", "Survivors" (mostly widows and widowers of persons entitled to social support who have not acquired these rights themselves), "Family and children", "Unemployment", "Housing" and "Other", referring to social exclusion and social protection n.e.c.

The main type of social spending was on "Old age", which mostly represents financial support to pension schemes. Its value varied between $4.73 \%$ of the GDP in Ireland and $14.53 \%$ of the GDP in Greece. The minimum

Table 2 Average government social spending in EU countries in 2008-2018 by category (\% of GDP)

\begin{tabular}{|c|c|c|c|c|c|c|c|}
\hline Country & $\begin{array}{l}\text { Family } \\
\% \text { of GDP }\end{array}$ & Housing & Old age & Sickness & Survivors & Unemployment & Other \\
\hline Austria & 2.37 & 0.12 & 12.64 & 1.94 & 1.47 & 1.35 & 1.11 \\
\hline Belgium & 2.31 & 0.20 & 8.67 & 2.99 & 1.82 & 2.14 & 1.25 \\
\hline Bulgaria & 2.34 & 0.12 & 9.40 & 0.24 & n.a & 0.10 & 0.58 \\
\hline Croatia & 1.87 & 0.07 & 8.68 & 2.17 & 1.41 & 0.50 & 0.93 \\
\hline Cyprus & 2.49 & 0.01 & 5.51 & 0.59 & 1.35 & 0.83 & 2.10 \\
\hline Czech Rep & 1.20 & 0.21 & 7.59 & 2.27 & 0.61 & 0.27 & 0.66 \\
\hline Denmark & 4.80 & 0.70 & 8.04 & 4.93 & 0.00 & 2.94 & 2.34 \\
\hline Estonia & 2.23 & 0.00 & 6.96 & 2.10 & 0.10 & 1.24 & 0.29 \\
\hline Finland & 3.19 & 0.40 & 12.03 & 3.97 & 0.77 & 2.26 & 1.44 \\
\hline France & 2.41 & 0.91 & 13.29 & 2.80 & 1.55 & 1.92 & 1.22 \\
\hline Germany & 1.65 & 0.42 & 9.36 & 3.03 & 1.91 & 1.86 & 1.18 \\
\hline Greece & 0.73 & 0.07 & 14.53 & 1.61 & 1.70 & 0.72 & 0.35 \\
\hline Hungary & 2.15 & 0.39 & 7.30 & 3.21 & 1.17 & 0.49 & 1.03 \\
\hline Ireland & 1.98 & 0.95 & 4.73 & 2.56 & 0.81 & 2.05 & 0.57 \\
\hline Italy & 0.98 & 0.01 & 13.46 & 1.76 & 2.64 & 1.05 & 0.60 \\
\hline Latvia & 1.39 & 0.11 & 6.18 & 3.13 & 0.38 & 0.61 & 0.62 \\
\hline Lithuania & 1.03 & 0.11 & 7.50 & 2.13 & 0.22 & 0.56 & 0.67 \\
\hline Luxembourg & 3.55 & 0.04 & 10.03 & 2.35 & 0.00 & 1.46 & 0.89 \\
\hline Malta & 1.06 & 0.15 & 7.60 & 1.29 & 1.57 & 0.43 & 0.75 \\
\hline Netherlands & 1.48 & 0.43 & 6.49 & 4.59 & 0.14 & 1.72 & 1.64 \\
\hline Poland & 1.69 & 0.07 & 9.22 & 2.45 & 1.73 & 0.53 & 0.39 \\
\hline Portugal & 1.09 & 0.21 & 11.68 & 1.45 & 1.75 & 1.14 & 0.71 \\
\hline Romania & 1.09 & 0.00 & 9.16 & 1.01 & 0.10 & 0.16 & 0.63 \\
\hline Slovakia & 1.31 & 0.00 & 7.59 & 2.84 & 0.86 & 0.21 & 2.03 \\
\hline Slovenia & 2.11 & 0.00 & 10.57 & 2.42 & 1.56 & 0.69 & 1.09 \\
\hline Spain & 0.77 & 0.05 & 8.62 & 2.39 & 2.24 & 2.58 & 0.49 \\
\hline Sweden & 2.45 & 0.30 & 10.57 & 4.21 & 0.35 & 1.36 & 1.12 \\
\hline UK & 1.73 & 1.28 & 8.51 & 2.41 & 0.10 & 0.24 & 1.90 \\
\hline
\end{tabular}

Maximum in bold, minimum in italics

Source Own calculation on the basis of Eurostat data, access 17.10.2020 
share of spending on "Old age" in the total social expenditure was $15.09 \%$ in Ireland in 2018, and the maximum share was $74.53 \%$ in Greece in 2010.

The maximum average spending on helping the sick and disabled was found in the Netherlands. The Dutch government spent the equivalent of $4.59 \%$ of its GDP yearly on this type of social support during the analysed period of ten years. The highest average yearly expenditures on family and children as well as unemployment were in Denmark at $4.8 \%$ and $2.94 \%$ of the GDP, respectively, and it was the highest on housing in the UK at $1.28 \%$ of the GDP. The category of social spending called "Survivors" is very specific, and in some countries, it does not exist. Its functioning depends on the construction of social security schemes, the age and gender structure of the society and the economic activity of women. The amount of yearly social spending on survivors ranged from $0.0 \%$ of the GDP in Luxembourg and Denmark up to $2.64 \%$ of the GDP in Italy and $2.24 \%$ of the GDP in Spain.

The cluster analysis indicated noticeable differences between the EU countries in terms of the value of social expenditure in relation to the GDP achieved in these countries. This was confirmed, in part, by selection tests of different numbers of clusters indicating that the optimum number was five. The ANOVA aggregated results for five clusters in particular years also proved cross-group differentiation, which accounted for 329.17 in 2010 and up to 526.78 in 2017, with differentiation within groups ranging from 9.85 in 2010 to 24.3 in 2013 $(p<0.00001)$.

After assigning countries to clusters using hierarchical cluster analysis by means of both the Ward method and $k$-means clustering, the findings from particular years were compared. The results of both methods were similar. Consequently, it was possible to establish which countries within the whole analysed period always fell into the same cluster. A set of such countries was referred to as a group. It was determined that six such groups could be identified. In Table 3, they are marked with the letters A-F. Results indicated that, over the eleven analysed years, some countries did not belong to another cluster only once, compared to the other countries from the group. They were designated as subgroups B1, C1 and D. For example, Austria differs from the countries in B group only in 2013 and as a result is marked B1. The high number of groups, the biggest of which consists of three countries, and the group with a subgroup of four countries, confirms the considerable differentiation across countries based on the analysed criteria.

In many cases, similar groups were made up of neighbouring countries, as in Austria with Germany, Spain with Portugal, Ireland with the UK, and Belgium with
France. Similarities were also observed between countries that are geographically quite dispersed, such as Romania and Lithuania or Denmark with Slovakia. In the case of neighbouring countries, similarities in terms of social expenditure share in GDP might be explained by cultural and historical factors. They follow the pattern of countries with similar welfare models pointed out in the Introduction. Neighbouring societies may expect their governments to implement social solutions similar to those adopted by their neighbours. It can be more challenging to explain the similarities between the countries that are far from each other. The reasons should instead be found in the economic and social policy of those countries.

Dividing government social spending into the seven types listed above, it was even more challenging to group EU countries into homogeneous clusters. The indicators of quality of clustering confirmed that the optimal number of clusters was two, and yet, the silhouette index ranged between 0.32 and 0.4 , indicating low similarity of objects within clusters. The results of the analysis of predictors' importance in influencing variability with the C\&RT model are presented in Table 4 . The analysis was run for each year separately.

As can be observed, spending on the "Unemployment", "Survivors" as well as the "Sickness and disability " had the strongest influence on the variability of government social spending across EU countries. The case of the "Survivors" category should be considered with caution, as in six out of 10 years, ANOVA indicated this predictor was statistically insignificant in differentiating the countries. The least influence on variability was noted in spending on "Old age", although this variable was considered a significant predictor. However, the similarity lies in the fact that in each EU country, this category has the biggest and most stable share of social spending, mostly due to their ageing societies [32].

Following the methodology for grouping and clustering used in Table 3, as well as the above analysis of the quality of the clusters, the EU countries were divided into two homogeneous clusters using seven categories of social expenditure as predictors of variability. After running the analysis for each year separately, a comparison of the results indicated one large group of EU countries that is relatively homogeneous in terms of volume and structure of social spending. The countries making up this homogeneous group are Austria, Croatia, Cyprus, Estonia, Finland, France, Hungary, Latvia, Malta, the Netherlands, Portugal, Romania, Slovakia, Spain and Sweden. Results also indicated a smaller group consisting of Denmark, Germany, Poland and Slovenia, though there was some variability within this group in 2015. The similarity of Belgium, the Czech Republic, Ireland, Italy, Lithuania, 
Table 3 Clusters established with the k-means method and groups of EU countries by similar social expenditure value

\begin{tabular}{|c|c|c|c|c|c|c|c|c|c|c|c|c|}
\hline \multirow[t]{3}{*}{ Country } & \multicolumn{11}{|c|}{ Cluster's number } & \multirow[t]{3}{*}{ Group } \\
\hline & \multicolumn{11}{|l|}{ Year } & \\
\hline & 2008 & 2009 & 2010 & 2011 & 2012 & 2013 & 2014 & 2015 & 2016 & 2017 & 2018 & \\
\hline Greece & 1 & 1 & 4 & 1 & 1 & 3 & 1 & 2 & 1 & 1 & 1 & A \\
\hline Netherlands & 1 & 1 & 4 & 1 & 1 & 3 & 1 & 2 & 1 & 1 & 1 & A \\
\hline Italy & 1 & 1 & 4 & 1 & 1 & 3 & 1 & 2 & 1 & 1 & 1 & A \\
\hline Belgium & 2 & 2 & 2 & 2 & 2 & 2 & 2 & 2 & 2 & 2 & 2 & B \\
\hline France & 2 & 2 & 2 & 2 & 2 & 2 & 2 & 2 & 2 & 2 & 2 & B \\
\hline Austria & 2 & 2 & 2 & 1 & 1 & 3 & 1 & 2 & 1 & 1 & 1 & B1 \\
\hline Germany & 2 & 2 & 2 & 2 & 1 & 2 & 1 & 2 & 2 & 2 & 2 & B1 \\
\hline Denmark & 3 & 3 & 3 & 5 & 5 & 4 & 4 & 1 & 4 & 4 & 4 & C \\
\hline Slovakia & 3 & 3 & 3 & 5 & 5 & 4 & 4 & 1 & 4 & 4 & 4 & C \\
\hline Portugal & 3 & 3 & 3 & 5 & 5 & 3 & 4 & 1 & 4 & 4 & 4 & $\mathrm{C} 1$ \\
\hline Spain & 4 & 3 & 3 & 5 & 5 & 3 & 4 & 1 & 4 & 4 & 4 & C1 \\
\hline Croatia & 4 & 4 & 1 & 4 & 4 & 4 & 3 & 4 & 3 & 3 & 3 & D \\
\hline Czech Rep & 4 & 4 & 1 & 4 & 4 & 4 & 3 & 4 & 3 & 3 & 3 & D \\
\hline Ireland & 4 & 4 & 1 & 4 & 4 & 4 & 3 & 3 & 5 & 5 & 5 & D1 \\
\hline UK & 4 & 4 & 1 & 4 & 4 & 4 & 3 & 4 & 3 & 3 & 3 & D1 \\
\hline Latvia & 5 & 5 & 5 & 3 & 3 & 1 & 5 & 3 & 5 & 5 & 5 & E \\
\hline Malta & 5 & 5 & 5 & 3 & 3 & 1 & 5 & 3 & 5 & 5 & 5 & $\mathrm{E}$ \\
\hline Romania & 5 & 5 & 5 & 3 & 3 & 1 & 5 & 3 & 5 & 5 & 5 & E \\
\hline Bulgaria & 5 & 5 & 5 & 3 & 3 & 5 & 3 & 5 & 3 & 3 & 3 & $\mathrm{~F}$ \\
\hline Cyprus & 5 & 5 & 5 & 3 & 3 & 5 & 3 & 5 & 3 & 3 & 3 & $\mathrm{~F}$ \\
\hline Sweden & 3 & 3 & 1 & 4 & 4 & 4 & 3 & 4 & 4 & 4 & 4 & G1 \\
\hline Poland & 3 & 4 & 1 & 4 & 4 & 4 & 3 & 4 & 4 & 4 & 4 & G1 \\
\hline Luxembourg & 1 & 1 & 4 & 5 & 5 & 3 & 4 & 1 & 4 & 4 & 1 & None \\
\hline Hungary & 1 & 3 & 3 & 5 & 4 & 4 & 3 & 5 & 3 & 3 & 3 & None \\
\hline Finland & 3 & 1 & 4 & 5 & 5 & 3 & 1 & 2 & 1 & 1 & 1 & None \\
\hline Slovenia & 3 & 3 & 4 & 5 & 5 & 3 & 4 & 1 & 4 & 4 & 4 & None \\
\hline Lithuania & 4 & 3 & 1 & 3 & 3 & 5 & 5 & 5 & 5 & 3 & 3 & None \\
\hline Estonia & 5 & 4 & 5 & 3 & 3 & 1 & 5 & 5 & 3 & 3 & 3 & None \\
\hline
\end{tabular}

Source Own calculations based on the data from Eurostat

Table 4 Ranking of predictors of heterogeneity

\begin{tabular}{|c|c|c|c|c|c|c|c|c|c|c|}
\hline \multirow[t]{2}{*}{ Predictor } & \multicolumn{10}{|l|}{ Year } \\
\hline & 2009 & 2010 & 2011 & 2012 & 2013 & 2014 & 2015 & 2016 & 2017 & 2018 \\
\hline Housing & +++ & +++ & + & + & + & + & + & + & ++ & + \\
\hline Sickness & +++ & +++ & + & + & + & +++ & ++ & +++ & +++ & ++ \\
\hline Survivors & ++ & ++ & +++ & +++ & ++ & ++ & +++ & +++ & ++ & + \\
\hline Family & + & + & + & + & ++ & +++ & + & +++ & + & + \\
\hline Unemployment & + & + & ++ & +++ & +++ & ++ & +++ & +++ & +++ & +++ \\
\hline Old age & + & + & ++ & ++ & +++ & + & +++ & +++ & +++ & ++ \\
\hline Other & ++ & + & + & + & ++ & +++ & + & +++ & ++ & + \\
\hline
\end{tabular}

$a$ importance of a predictor, " +++ "means $1>a \geq 0.7, "++" 0.7>a \geq 0.5, "+" a<0.5$

Source Own calculations 
Luxembourg and the UK to other countries was changing, making it impossible to allocate them into homogeneous groups.

\section{Conclusions}

This study of the volume of social expenditure points to the high differentiation of EU countries in this respect. Some similarities were observed only for small groups of countries whose inter-group differentiation was high. The results obtained help create some perspective on problems that such a situation might create for EU countries and pose further research questions.

The variability across EU countries in terms of social spending on unemployment may result from different economic factors. Surprisingly, high unemployment rates can be observed in countries recording high demand in the workforce. With higher social benefits, the unemployed tend to spend more time on thorough job market recognisance, enabling them to seek better-tailored jobs. Consequently, job applicants appear to be more productive once they are hired. This, in turn, brings about higher earnings and lower social spending in the future.

Regarding survivors, exceptionally high differentiation indicates a need for further research their problems, particularly in the case of Italy and Malta.

As pointed out previously, high social expenditure may have a negative effect on the level of domestic savings as well as the economic activities of the population. However, the realisation of a number of the EU schemes has been connected with bearing the cost of this sort of expenditure, mainly within policies to combat poverty and social inequalities.

High differentiation of social expenditure in relation to GDP in individual countries is not conductive to support running a common policy within the EU. It also induces the population to make demands aimed at forcing their authorities to extend social support similar to that in the countries with the most developed schemes. This makes it challenging to pursue an efficient economic policy and, additionally, increases the likelihood of social unrest. It must be emphasised that the goal of social integration is not realised through common social policy but through the improvement of the wellbeing of EU citizens with a focus on reducing inequality. Therefore, understanding the differences serves to help identify sources of social problems and adjust different policies accordingly.

\footnotetext{
Abbreviations

EU: European Union; GDP: Gross domestic product; Max: Maximum; Min: Minimum; St. Dev: Standard Deviation; UK: United Kingdom.
}

Authors' contributions

All contributions were made by the single author.

Funding

There is no special funding for this research.

\section{Availability of data and materials}

The datasets analysed during the current study are avilable in the EUROSTAT repository, table: General government expenditure by function (COFOG) [gov_10a_exp].

\section{Declarations}

Competing interests

There are no competing interests.

Received: 3 April 2021 Accepted: 12 July 2021

Published: 24 July 2021

\section{References}

1. Aghabozorgi S, Seyed Shirkhorshidi A, Ying Wah T (2015) Time-series clustering: a decade review. Inf Syst 53:16-38. https://doi.org/10.1016/j.is. 2015.04.007

2. Anderson E, Jalles D'Orey MA, Duvendack M, Esposito L (2018) Does government spending affect income poverty? A meta-regression analysis. World Dev 103:60-71. https://doi.org/10.1016/j.worlddev.2017.10.006

3. Anderson E, Jalles D'Orey MA, Duvendack M, Esposito L (2017) Does government spending affect income inequality? A meta-regression analysis. J Econ Surv 31(4):961-987. https://doi.org/10.1111/joes.12173

4. Ando A, Modigliani F (1963) The "life-cycle" hypothesis of saving: aggregate implications and tests. Am Econ Rev 53:55-84

5. Andreotti A, Mingione E (2016) Local welfare systems in Europe and the economic crisis. Eur Urban Reg Stud 23(3):252-266. https://doi.org/10. $1177 / 0969776414557191$

6. Antonelli MA, De Bonis V (2016) Clustering European welfare systems through a performance. Public finance research papers 18: Issue April. http://www.digef.uniroma1.it/ricerca

7. Antonelli MA, De Bonis V (2018) Assessing the performance of social spending in Europe. Central Eur J Public Policy 12(1):17-31. https://doi. org/10.2478/CEJPP-2018-0001

8. Arrondel L, Bartiloro L, Fessler P, Lindner P, Mathä TY, Rampazzi C, Savignac F, Schmidt T, Schürz M, Vermeulen P (2016) How do households allocate their assets? Stylized facts from the eurosystem household finance and consumption survey. Int J Central Bank 44:129-220

9. Arrondel L, Roger M, Savignac F (2014) Wealth and income in the Euro Area: heterogeneity in households' behaviours. In: Direction Générale des Études et des Relations Internationales 497: Issue July

10. Bericat $E$ (2019) The quality of European societies: an overview. In: Bericat E, Jiménez-Rodrigo ML (eds) The quality of European societies : a compilation of composite indicators. Social indicators research series, vol 75. Springer, https://doi.org/10.1007/978-3-030-05023-8

11. Bertola G, Jimeno JF, Marimon R, Pissarides C (2001) EU welfare systems and labor markets: diverse in the past, integrated in the future? In: Bertola G, Boeri T, Nicoletti G (eds) Welfare and employment in a United Europe: a study for the Fondazione Rodolofo Debenedetti. MIT Press, United Europe. http://search.ebscohost.com/login.aspx?direct $=$ true $\& \mathrm{db}=\mathrm{e} 000 \mathrm{x}$ ww\&AN=138605\&lang =pl\&site=ehost-live

12. Boskin MJ, Hurd MD (1978) The effect of social security on early retirement. J Public Econ 10(3):361-377. https://doi.org/10.1016/00472727(78)90052-X

13. Bradshaw J (2012) The case for family benefits. Child Youth Serv Rev 34(3):590-596. https://doi.org/10.1016/j.childyouth.2011.10.009

14. Chen X (2017) Globalization and household saving: is there a link? Appl Econ 49(29):2797-2816. https://doi.org/10.1080/00036846.2016.1248355

15. Çolak MS, Ege A (2013) An assessment of EU 2020 strategy: Too far to reach? Soc Indic Res 110(2):659-680. https://doi.org/10.1007/ s11205-011-9950-2 
16. Cyrek M (2019) Government social spending in the EU countries: efficiency in poverty and income inequality reduction. Equilibrium 14(3):405-424. https://doi.org/10.24136/eq.2019.019

17. Darvas Z (2019) Why is it so hard to reach the EU's poverty target? Soc Indic Res 141(3):1081-1105. https://doi.org/10.1007/s11205-018-1872-9

18. EUROPE 2020 (2010) A European strategy for smart, sustainable and inclusive growth. Testimony of European Commission

19. Everitt B (1980) Cluster analysis. Qual Quant 14(1):75-100. https://doi.org/ 10.1007/BF00154794

20. Feldstein M (1980) The effect of social security on saving. Geneva Papers Risk Insurance Iss Pract 5(1):4-17

21. Feldstein M (1996) Social security and saving: new time series evidence. Natl Tax J 49(2):151-164

22. Ferrer A, Gagné L (2013) Family-friendly benefits? J Manag Organ 19(6):721-741. https://doi.org/10.1017/jmo.2014.13

23. Fessler P, Schürz M (2015) Private wealth across European countries: the role of income, inheritance and the welfare state. J Hum Dev Capab 19(4). EBC Working Paper no 1847. Routledge. https://doi.org/10.1080/19452 829.2018.1507422

24. Fraley C, Raftery AE (1998) How many clusters? Which clustering method? Answers via model-based cluster analysis. Comput J 41(8):578-588. https://doi.org/10.1093/comjnl/41.8.578

25. Frigui $\mathrm{H}$ (2008) Cluster analysis: basic concepts and algorithms. Clustering: algorithms and applications. In: 2008 first workshops on image processing theory, tools and applications. https://doi.org/10.1109/IPTA. 2008.4743793

26. Gerlinger T, Urban HJ (2007) From heterogeneity to harmonization? Recent trends in European health policy. Cadernos de Saude Publica 23(Suppl. 2):S133-S142. https://doi.org/10.1590/S0102-311X200700 1400003

27. Guin B (2017) Culture and household saving. ECB working paper series No. 2069: Issue November. https://doi.org/10.1093/jnci/djv313

28. Gustman AL, Steinmeier TL (2015) Effects of social security policies on benefit claiming, retirement and saving. J Public Econ 129:51-62. https:// doi.org/10.1016/j.jpubeco.2015.07.005

29. Haile F, Niño-Zarazúa M (2018) Does social spending improve welfare in low-income and middle-income countries? J Int Dev 30(3):367-398. https://doi.org/10.1002/jid.3326

30. Haliassos M, Jansson T, Karabulut Y (2014) Incompatible European partners? Cultural predispositions and household financial behavior. Manage Sci 63(58):1-65. https://doi.org/10.1287/mnsc.2016.2538

31. Hartigan JA (1985) Statistical theory in clustering. J Classif 2(1):63-76. https://doi.org/10.1007/BF01908064

32. Henjak A (2008) Population ageing and distributive conflicts: age distributive divisions in western Europe. Revija Za Socijalnu Politiku 15(2):189-207. https://doi.org/10.3935/rsp.v15i2.704

33. Höpner M, Schäfer A (2012) Integration among unequals: how the heterogeneity of European varieties of capitalism shapes the social and democratic potential of the EU (12/5; MPIfG discussion paper). www. mpifg.de

34. Jafarov E, Gunnarsson V (2008) Efficiency of government social spending in croatia. Financial Theory Pract 32(3):289-320
35. Kaufman L, Rousseeuw PJ (2005) Finding groups in data. An introduction to cluster analysis. John Wiley \& Sons Inc, New York

36. König J, Ohr R (2012) The European Union-a heterogeneous community? Implications of an index measuring European integration. www.eu-index. de

37. Košmelj K, Batagelj V (1990) Cross-sectional approach for clustering time varying data. J Classif 7(1):99-109. https://doi.org/10.1007/BF01889706

38. Kotlikoff LJ (1989) Social security and equilibrium capital intensity. In: What determines saving? pp 316-336. MIT Press

39. Lance GN, Williams WT (1967) A general theory of classificatory sorting strategies: 1. Hierarchical systems. Comput J 9(4):373-380. https://doi. org/10.1093/comjnl/9.4.373

40. Le Blanc J, Porpiglia A, Teppa F, Zhu J, Ziegelmeyer M (2016) Household saving behavior in the Euro area. Int J Cent Bank 12(2):15-68

41. MacQueen J (1967) Some methods for classification and analysis of multivariate observations. In: Le Cam LM, Neyman J (eds) Proceedings of the fifth Berkeley symposium on mathematical statistics and probability: biology and problems of health. University of California Press, pp 281-297. https://doi.org/10.1007/s11665-016-2173-6

42. Magda I, Kiełczewska A, Brandt N (2018) The "Family 500+" child allowance and female labour supply in Poland. OECD Economics Department Working Papers 1481. https://doi.org/10.1787/1a30745e-en

43. Murtagh F, Legendre P (2014) Ward's hierarchical agglomerative clustering method: Which algorithms implement ward's criterion? J Classif 31(3):274-295. https://doi.org/10.1007/s00357-014-9161-z

44. Pasimeni P (2013) The Europe 2020 index. Soc Indic Res 110(2):613-635. https://doi.org/10.1007/s11205-011-9948-9

45. Piłatowska M (2006) Repetytorium ze statystyki. Wydawnictwo Naukowe PWN

46. Pociecha J, Podolec B, Sokołowski A, Zając K (1988) Metody taksonomiczne w badaniach społeczno-ekonomicznych. Państwowe Wydawnictwo Naukowe

47. Rószkiewicz M (2008) Zmienność stopy oszczędzania polskich gospodarstw domowych. Gospodarka Narodowa 7-8:63-79

48. Sánchez Á, Pérez-Corral AL (2018) Government social expenditure and income inequalities in the European Union. Rev Public Econ 227(4/2018):133-156. https://doi.org/10.7866/HPE-RPE.18.4.5

49. Walesiak M, Gatnar E (eds) (2009) Statystyczna analiza danych z wykorzystaniem programu R. Wydawnictwo Naukowe PWN

50. Walheer B (2018) Decomposing the Europe 2020 index. Soc Indic Res. https://doi.org/10.1007/s11205-017-1797-8

51. Warren Liao T (2005) Clustering of time series data: a survey. Pattern Recogn 38(11):1857-1874. https://doi.org/10.1016/j.patcog.2005.01.025

\section{Webgraphy}

52. General government expenditure by function (COFOG), Eurostat, GOV_ 10A EXP (2020)

\section{Submit your manuscript to a SpringerOpen ${ }^{\circ}$ journal and benefit from:}

- Convenient online submission

- Rigorous peer review

- Open access: articles freely available online

- High visibility within the field

Retaining the copyright to your article

Submit your next manuscript at $>$ springeropen.com 